\title{
PENINGKATAN MOTIVASI BELAJAR SISWA MATERI SIFAT-SIFAT CAHAYA DAN MANFAATNYA PADA MATA PELAJARAN IPA DENGAN MENGGUNAKAN PENDEKATAN METODE KETERAMPILAN PROSES DAN IMPLIKASINYA TERHADAP HASIL BELAJAR YANG DICAPAI SISWA KELAS V DI SD NEGERI CIGASONG III
}

\author{
Ari Yanto \\ ari.thea86@gmail.com \\ Universitas Majalengka
}

\begin{abstract}
ABSTRAK
Penelitian ini dilatarbelakangi masih rendahnya nilai IPA khususnya pada materi sifat-sifat cahaya pada tahun ajaran 2014/2015. KKM yang di tentukan adalah 70. Dari jumlah siswa sebanyak 34 siswa, dimana yang mencapai KKM hanya 9 siswa dan yang tidak mencapai KKM 25 sisswa, siswa yang mencapai KKM hanya 26,5\% dengan rata-rata kelas 73,5\%. Sedangkan pada tahun ajaran 2015/2016 KKM yang ditentukan masih sama dengan KKM tahun yang lalu yaitu 70, berdasarkan dokumen dengan jumlah 36 siswa yang mencapai KKM hanya 16 siswa dan yang tidak mencapai KKM berjumlah 20 siswa, siswa yang mencapai KKM $44.4 \%$ dengan rata-rata kelas $56.5 \%$. bertujuan untuk mengetahui peningkatan motivasi belajar materi sifatsifat cahaya dan manfaatnya pada mata pelajaran IPA dengan menggunakan pendekatan metode keterampilan proses dan implikasinya terhadap hasil belajar yang dicapai siswa kelas V SDN Cigasong III. Penelitian ini merupakan Penelitian Tindakan Kelas dimana penelitian ini di kelas V SDN Cigasong III sebanyak 36 siswa terdiri dari 17 siswa laki-laki dan 19 siswa perempuan. Teknik yang digunakan dalam pengumpulan data adalah tes, observasi, wawancara dan dokumentasi. Data yang diperoleh berupa hasil tes sebagai data primer dan hasil observasi, wawancara serta dokumentasi sebagai bahan pendukung. Teknik analisis data yang digunakan adalah analisis deskriptif kualitatif untuk menganalisis hasil tes akhir setiap tindakan dan analisis deskriptif untuk hasil observasi setiap tindakan. Penelitian dilaksanakan dalam 2 siklus. Hasil penelitian menunjukkan bahwa penerapan metode keterampilan proses implikasinya terhadap Hasil Belajar dalam pelajaran Ilmu Pengetahuan Alam (IPA) dapat meningkatkan motivasi belajar siswa kelas V SDN Cigasong III. Hal ini ditunjukan dengan adanya peningkatan nilai sebelum pemberian tindakan hingga siklus II. Nilai rata-rata kelas sebelum pemberian tindakan adalah 56,50 sedangkan persentase siswa yang mencapai ketuntasan belajar adalah 44,40\%. Pada siklus I nilai rata-rata kelas yang diperoleh siswa 71,80 sedangkan persentase siswa yang mencapai ketuntasan belajar adalah $69,40 \%$. Pada siklus II nilai rata-rata kelas yang diperoleh siswa 81,2 sedangkan persentase siswa yang mencapai ketuntasan belajar adalah $91,70 \%$. Kesimpulan, Adanya peningkatan motivasi belajar siswa materi sifat-sifat cahaya dan manfaatnya dalam pembelajaran IPA dengan menggunakan pendekatan metode keterampilan proses dan implikasinya terhadap hasi belajar yang dicapai siswa kelas V di SD Negeri Cigasong III
\end{abstract}

Kata Kunci: Motivasi Belajar Siswa, Pendekatan Metode Keterampilan Proses dan implikasinya terhadap Hasil Belajar 


\section{PENDAHULUAN}

Memang harus diakui masih banyak di antara para siswa, yang ketika belajar dirinya belum terbangun semangat di dalam belajarnya dengan motivasi yang kuat, dampaknya adalah tujuan yang ingin dicapai dalam belajarnya itu tidak dapat tercapai.

Hasil belajar adalah merupakan harapan dan keinginan dari setiap guru yang mengajar di kelas, namun untuk mencapainya tentunya harus banyak cara atau strategi tertentu yang dilakukan oleh setiap guru di dalam proses pebelajarannya. Pemilihan media yang tepat adalah merupakan salah satu langkah yang harus benar-benar diperhatikan oleh setiap guru, sebab tidak menutup kemungkinan penerapan media yang salah atau tidak sesuai dengan materi yang diajarkannya itu, akan menjadi suatu kendala dalam pemahaman materi yang diajarkan guru terhadap para siswanya tersebut. media keterampilan proses ini, adalah satu media yang mampu memberikan dorongan motivasi bagi para siswa untuk belajar menggali tentang materi yang diajarkannya dan diharapkan para siswa juga menmukan suatu jawaban yang diharapkannya itu. Jika penerapan media ini, mampu dilakukan dalam proses pembelajaran, tentunya hasil belajar yang ingin dicapainya itu akan menjadi kenyataan terhadap apa yang menjadi tujuan dari pembelajaran tersebut, baik bagi guru sendiri lebih-lebih bagi setiap siswa.

Materi sifat-sifat cahaya dan manfaatnya pada mata pelajaran IPA yang diajarkan terhadap siswa kelas V di SD Negeri Cigasong III, masih banyak mengalami kendala yang dihadapi siswa, kenapa hal itu bisa terjadi, karena masih belum banyak bagi seorang guru yang mengajarkan materi IPA tersebut menerapkan media yang tepat di dalam menyampaikan materi yang diajarkannya, sehingga yang terjadi adalah siswa tidak memahami dari materi yang diajarkan tersebut, ditambah lagi motivasi belajar yang dimiliki oleh setiap siswa sangat rendah sekali. Hal inilah yang menjadikan semangat saya untuk mencoba dengan menerapkan pendekatan media keterampilan proses pada materi yang diajarkannya itu. Harapan dari apa yang menjadi suatu keinginan ini, tentunya hasil belajar yang diharpkan itu akan terealisasi, sehingga setiap siswa hasil belajarnya akan tercapai dari yang diharapkannya itu.

Bagi para guru hendaknya memiliki kesadaran, agar apa yang dihadapi di dalam proses pembelajaran yang berlangsung di kelas tersebut, menyenagkan bagi siswa, sehingga harapannya adalah siswa memiliki motivasi yang tinggi di dalam belajarnya. Kesadran ini hendaknya menjadi pemicu bagi para guru dalam membangun motovasi belajar terhadap para siswanya. Jika hal itu mampu direalisasikan dalam proses belajar mengajar di kelas, maka tidak menutup kemungkinan pencapaian yang dimaksud terhadap hasil belajar tersebut, akan menjadi kenyataan. Guru hendaknya selalu melakukan inovasi-inovasi bari di dalam pemeblajaran, dengan berusaha untuk menemukan media yang tepat ketika menyampaikan materi yang diajarkannya tersebut, karena diakui atau tidak pada pembelajaran saat ini, diaman tingkat pemahaman siswa terhadap materi seharusnya lebih memudahkan dari apa yang disampaikan oleh para gurunya tersebut, selama proses pembelajaran yang berlangsung di kelas itu. Inilah yang menjadi suatu keinginan besar di lembagalembaga pendidikan terutama di sekolah dasar. Jika hal itu mampu diwujudkan maka secara langsung atau tidak langsung hasil belajar yang menjadi tujuannya itu akan tercapai dengan hasil yang memuaskan.

Pendekatan media keterampilan proses banyak memberikan kesempatan bagi setiap siswa untuk mengembangkan potensi yang ada pada dirinya itu, untuk terus berusaha mangkaji dan menemukan suatu jawaban yang diharapkan dari materi yang diberikan itu, sehingga akhirnya para siswa akan lebih mudah untuk mengetahui akan hasil dari jawabab yang dikehendakinya. Banyak kelebihan dan 
manfaat yang dapat dilakukan atau digunakan bagi para siswa untuk memahami dari suatu persoalan yang ada pada materi tersebut, hal inilah yang terus dikembangkan oleh para guru dalam memberikan penjelasan-penjelasan dari apa yang diajarkan di kelas terhadap para siswanya. Namun hal itu juga bagi setiap guru tentunya harus menyadari, bahwa dibalik manfaat yang didapatkan dari pendekatan media keterampilan proses ini, tentunya ada faktor-faktor yang harus diperhatikan agar kekuranga yang ada pada penggunaan media keterampilan proses itu dapat diantisifasi dengan hal-hal yang lainnya sebagai media pendukung. Di antara faktor-faktor kelemahan itu adalah pemahaman siswa yang harus terus diperhatikan karena bagaimanapun siswa masih perlu untuk diarahkan dan dibimbing oleh setiap guru agar keberhasilan yang diharapkan tersebut tidak menjadi penghalang dalam proses pebelajaran yang berlangsung di kelas.

Dari hasil dokumentasi yang ada, terhadap nilai IPA khususnya pada materi sifat-sifat cahaya, pada tahun 2014/2015 KKM yang ditentukan adalah 70. Dari jumlah 34 siswa, dimana yang mencapai KKM hanya 9 siswa dan yang tidak mencapai KKM 25 siswa, siswa yang mencapai KKM hanya $26.5 \%$ dengan ratarata kelas $73.5 \%$. Sedangkan pada tahun 2015/2016 KKM yang ditentukan masih sama dengan KKM tahun yang lalu yaitu 70, berdasarkan dari dokumen dengan jumlah 36 siswa yang mencapai KKM hanya 16 siswa dan yang tidak mencapai KKM berjumlah 20 siswa, siswa yang mencapai KKM $44.4 \%$ dengan rata-rata kelas $56.5 \%$. Dari data tersebut diketahui bahwa, ternyata pada mata pelajaran IPA pada materi sifat-sifat cahaya masih jauh dari KKM yang ditentukan.

\section{Pengertian metode Keterampilan Proses}

Pembelajaran adalah suatu proses interaksi yaitu hubungan timbal balik antara guru dengan siswa. Guru memberikan bimbingan dan menyediakan berbagai kesempatan yang dapat mendorong siswa belajar dan untuk memperoleh pengalaman sesuai dengan tujuan pembelajaran. Tercapainya tujuan pembelajaran ditandai oleh tingkat penguasaan kemampuan dan pembentukan kepribadian. Proses pembelajaran melibatkan berbagai kegiatan dan tindakan yang perlu dilakukan oleh siswa untuk memperoleh hasil belajar yang baik antara guru dengan siswa. Guru memberikan bimbingan dan menyediakan berbagai kesempatan yang dapat mendorong siswa belajar dan untuk memperoleh pengalaman sesuai dengan tujuan pembelajaran. Tercapainya tujuan pembelajaran ditandai oleh tingkat penguasaan kemampuan dan pembentukan kepribadian. Proses pembelajaran melibatkan berbagai kegiatan dan tindakan yang perlu dilakukan oleh siswa untuk memperoleh hasil belajar yang baik. Kesempatan untuk melakukan kegiatan dan perolehan hasil belajar ditentukan oleh pendekatan yang digunakan oleh guru dan siswa dalam proses pembelajaran tersebut.

$$
\text { Pembelajaran menggunakan }
$$

pendekatan keterampilan proses adalah proses pembelajaran yang dirancang sedemikian rupa sehingga siswa dapat menemukan fakta-fakta, membangun konsep-konsep dan teori-teori dengan keterampilan proses dan sikap ilmiah siswa sendiri (Soetardjo, 1998:3). Dalam pendekatan keterampilan proses, tugas guru adalah memberikan kemudahan kepada peserta didik dalam menciptakan lingkungan yang kondusif agar semua peserta didik dapat berkembang secara optimal.

Pembelajaran berdasarkan pendekatan keterampilan proses perlu memperhatikan hal-hal sebagai berikut:

1. Keaktifan peserta didik didorong oleh kemauan untuk belajar karena adanya tujuan yang ingin dicapai.

2. Keaktifan peserta didik akan berkembang jika dilandasi dengan pendayagunaan potensi yang dimilikinya.

3. Suasana kelas dapat mendorong atau mengurangi aktivitas peseta didik. 
Suasana kelas harus dikelola agar dapat merangsang aktivitas dan kreativitas belajar peserta didik.

4. Dalam kegiatan pembelajaran, tugas guru adalah memberikan kemudahan belajar melalui bimbingan dan motivasi untuk mencapai tujuan. Kegiatankegiatan yang dapat dilakukan untuk mendorong aktivitas dan kreativitas peserta didik dalam pembelajaran antara lain: diskusi, pengamatan, penelitian, praktikum, tanya jawab, karya wisata, studi kasus, bermain peran, dan kegiatan-kegiatan lain yang dapat menunjang tercapainya tujuan pembelajaran.

\section{Pengertian Hasil belajar}

Menurut Sardiman (2007: 51), "hasil belajar adalah hasil langsung berupa tingkah laku siswa setelah melalui proses belajar-mengajar yang sesuai dengan materi yang dipelajarinya". Sehingga hasil belajar dapat ditafsirkan sebagai output dari proses belajar-mengajar.

Apabila kita membicarakan tentang hasil belajar, tentunya banyak sekali pendapat yang memberikan tentang pengertian itu, seperti menurut pendapat Dimyati dan Mudjiono (2006) hasil belajar adalah hasil yang dicapai dalam bentuk angka-angka atau skor setelah diberikan tes hasil belajar pada setiap akhir pembelajaran. Nilai yang diperoleh siswa menjadi acuan untuk melihat penguasaan siswa dalam menerima materi pelajaran. Adapun menurut Djamarah dan Zain (2006) hasil belajar adalah apa yang diperoleh siswa setelah dilakukan aktifitas belajar.

Namun menurt Hamalik (2008) hasil belajar adalah sebagai terjadinya perubahan tingkah laku pada diri seseorang yang dapat di amati dan di ukur bentuk pengetahuan, sikap dan keterampilan. Perubahan tersebut dapat di artikan sebagai terjadinya peningkatan dan pengembangan yang lebih baik sebelumnya yang tidak tahu menjadi tahu. Mulyasa (2008) hasil belajar merupakan prestasi belajar siswa secara keseluruhan yang menjadi indikator kompetensi dan derajat perubahan prilaku yang bersangkutan.

Kompetensi yang harus dikuasai siswa perlu dinyatakan sedemikian rupa agar dapat dinilai sebagai wujud hasil belajar siswa yang mengacu pada pengalaman langsung.

Dari beberepa penjelasan tersebut, maka tentunya hasil belajar yang di dapatkan oleh siswa itu tentunya harus melalui beberapa proses yang dilakukannya dalam kegiatan belajar mengajar di kelas. Dengan adanya proses kegiatan itulah maka akan menghasilkan sesuatu yang dinamakan dengan hasil belajar, adapun cara untuk mengetahui tentang hasil belajar itu, dapat melalui tes tertulis atau melalui pengamatan yang dilakukan oleh seorang guru di kelas.

Dari gambaran-gambaran itulah maka sudah jelas apapun yang dilakukan oleh seseorang dalam aktifitasnya dalam belajar maka akan menghasilkan suatu hasil, dan itulah yang dinamakan dengan hasil belajar.

\section{METODE PENELITIAN}

Penelitian ini menggunakan metode Penelitian Tindakan Kelas (PTK). Penelitian Tindakan Kelas dikenal dengan istilah clssroom action research $(C A R)$.

Berdasarkan jenis penelitian yang dipilih, yaitu penelitian tindakan kelas, maka dalam penelitian ini, peneliti menggunakan model penelitian tindakan dari Kemmis dan Taggart yang berbentuk sepiral, model penelitian ini saling terkait dari siklus satu ke siklus berikutnya.

Kemmis dan Taggart menurut Yanto (2013:49). Mengatakan bahwa dalam perencanaannya Kemmis menggunakan sistem spiral merefleksi diri yang terbagi ke dalam beberapa siklus, meliputi Kemmis dan Mc Taggart yaitu perencanaan (plan), pelaksanaan dan pengamatan (act and observe), dan refleksi. Tahapan-tahapan tersebut harus disusun dan dilakukan secara berulang hingga hasil yang diinginkan tercapai. Pada setiap akhir siklus yaitu refleksi yang merupakan evaluasi, dijadikan 
bahan pertimbangan untuk perencanaan siklus selanjutnya. penelitian ini adalah siswa kelas $\mathrm{V}$ SD Negeri Cigasong III Kecamatan Cigasong Kabupaten Majalengka. Tahun pelajaran 2015-2016 dengan jumlah siswa 36 , adapun jumlah laki-laki 17 dan jumlah perempuan 19

Adapun untuk langkah alur pada setiap siklus dalam penelitian ini adalah penyusunan sutau rencana. Kemudian tahap berikutnya adalah melakukan suatu tindakan dan sekaligus juga melakukan pengamatan terhadap pelaksanaan tindakan. Hasil pengamatan kemudian dievaluasi dalam bentuk refleksi. Apabila hasil refleksi siklus pertama belum memberikan hasil sebagaimana yang diharapkan, yang berikutnya disusun lagi rencana untuk dilaksanakan pada siklus kedua. Dan seterusnya sampai hasil yang diinginkan benar-benar tercapai.

a. Mengumpulkan data yang diperlukan melalui teknik wawancara, observasi, dan hasil belajar siswa. Kemudian merancang pembelajaran untuk meningkatkan motivasi belajar siswa, yaitu dengan langkah-langkah:

1. Permasalahan

diidentifikasi/dirumuskan. Dalam hal ini guru menentukan materi pelajaran

2. Merancang pembentukan kelompok

3. Merancang pembentukan media pembelajaran

4. Menyiapkan soal yang berkaitan dengan materi pembelajaran

5. Menyiapkan lembar kegiatan diskusi dan soal-soal evaluasi siklus I

b. Pelaksanaan

Tindakan-tindakan yang dilakukan pada penelitian ini dapat diuraikan sebagi berikut:

1. Pendahuluan

Pada bagian ini guru melakukan apersepsi yaitu mengingat kembali tentang dongeng dengan menunjukan konsep sistem peredaran darah manusia. Kemudian memotivasi siswa untuk mengikuti pembelajaran dengan baik.

2. Kegiatan inti

Kegiatan ini guru mengajak siswa untuk bertanya jawab mengenai dongeng yang telah ditunjukan. Kemudian siswa dibagi menjadi 5 kelompok dan mendapat tugas untuk berdiskusi mengidentifikasi dongeng dan mebuat pertanyaan ditulis dikertas selembar, kemudian kertas yang berisi pertanyaan diremas-remas hingga mebuat bola kertas, lalu dilempar-lempar ke kelompok lain, dan siswa saling membantu dengan kelompoknya untuk menyelesaikan tugasnya.

3. Penutup

Pada kegiatan akhir pembelajaran metode pendekatan keterampilan proses dilakukan pemberian nilai hasil setiap kelompok dan penghargaan untuk kelompok terbaik. Kemudian menyimpulkan materi yang telah dipelajari dan mengadakan tes evaluasi akhir siklus I.

c. Pengamatan

Pengamatan dilakukan pada saat proses pembelajaran berlangsung. Guru terlibat langsung dalam kegiatan pembelajaran. Pengamatan dilakukan dengan menggunakan lembar pedoman observasi siswa yang berisi mengenai prilaku siswa selama pembelajaran berlangsung. Dari pengamatan tersebut dapat juga diketahui kendala yang terdapat pada hasil pengamatan siklus I sehingga dapat diperbaiki pada siklus II.

d. Refleksi

Setelah dilakukan tindakan, peneliti melakukan analisi terhadap hasil tes evaluasi, hasil observasi. Analisis ini bertujuan untuk mengetahui kelebihan dan kekurangan dalam proses pembelajaran siklus I, kelebihan dan kekurangan model pembelajaran media powerpoint, tindakan-tondakan yang dilakukan oleh siswa selama proses pembelajaran.

Lembar evaluasi ini bertujuan untuk membuktikan bahwa peneingkatan 
keaktifan siswa berpengaruh terhadap peningkatan hasil evaluasi siswa. Artinya, peningkatan keaktifan siswa berpengaruh terhadap peningkatan hasil belajar. Lembar evaluasi siswa merupakan data pendukung peningkatan keaktifan siswa dalam pembelajaran IPA materi yang diajarkan guna mengetahui sejauh mana pemahaman siswa terkait dengan materi yang diajukan.

Hasil penelitian pembelajaran yang telah dilaksanakan dianalisis untuk mengetahui ketercapaian pelaksanaan pembelajaran. Untuk mengukur hasil belajar atau hasil tes caranya dengan menentukan nilai rata-rata hasil penelitian. Dengan menjumlahkan nilai yang diperoleh siswa, kemudian dibagi dengan jumlah siswa kelas tersebut sehingga diperoleh nilai rata-rata.

$$
\mathrm{X}=\frac{\sum \mathrm{X}}{----}
$$

$\begin{array}{ll}\mathrm{X} & =\text { Nilai rata-rata } \\ \sum \mathrm{X} & =\text { Jumlah semua nilai siswa } \\ \sum N & =\text { Jumlah siswa }\end{array}$

\section{HASIL DAN PEMBAHASAN}

Dari hasil temuan refleksi terhadap permasalahan fokus penelitian pembelajaran hasil yang meningkat dalam mencapai nilai siswa pada pembelajaran IPA meningkat. Berdasarkan Grafik ditunjukkan terjadi peningkatan pada nilai siswa. Penguasaan konsep pembelajaran IPA mengalami peningkatan. Hal ini memperlihatkan adanya kemajuan dari hasil perbaikan pembelajaran yang dilakukan penulis.

Keadaan awal terdapat 34 siswa mendapat nilai lebih dari 60 , siklus I terdapat 33 siswa mendapat nilai lebih dari 60, dan pada siklus II terdapat 40 siswa mendapat nilai lebih dari 60

Setelah melakukan refleksi, maka diketahui keberhasilan dan kegagalan dari proses pembelajaran yang penulis lakukan, yaitu :

a. Keberhasilan
1) Dengan melakukan penggunaan pendekatan metode keterampilan proses dan implikasinya terhadap hasil belajar yang dicapai siswa kelas $\mathrm{V}$ dapat mengembangkan sikap keingintahuan siswa

2) Sikap ingin tahu siswa tidak hanya dimiliki oleh siswa yang prestasinya bagus.

b. Kegagalan

1) Masih ada siswa yang belum mempunyai sikap ingin tahu

2) Belum mampu membangkitkan motivasi seluruh siswa.

\section{Pembahasan dari Setiap Siklus}

\section{Siklus I}

Berdasarkan hasil refleksi dan diskusi dengan teman sejawat tentang proses penelitian pembelajaran mata pelajaran IPA Siklus I yang telah dilakukan memperoleh suatu peningkatan, hal ini dikarenakan siswa yang telah menguasai materi sejumlah 34 siswa. Hal ini dapat dilihat dari rincian nilai yang diperoleh siswa, yaitu siswa yang memperoleh nilai 8 sebanyak 19 siswa, nilai 7 sebanyak 14 siswa, dan nilai 6 sebanyak 7 siswa.

Tetapi secara keseluruhan, tujuan pembelajaran yang diharapkan belum tercapai dengan optimal. Sebagai langkah untuk menyikapinya penulis mencoba merefleksi dari tindakan perbaikan pembelajaran yang telah dilaksanakan, kemudian merencanakan kembali melakukan tindakan perbaikan pembelajaran pada siklus II.

\section{Siklus II}

Berdasarkan hasil refleksi dan diskusi dengan teman sejawat tentang proses penelitian pembelajaran mata pelajaran IPA siklus II, terlihat adanya suatu kemajuan yang sangat signifikan, karena seluruh siswa telah menguasai materi pelajaran. Hal ini dapat dilihat dari rincian nilai yang diperoleh siswa, yaitu siswa yang memperoleh nilai 10 sebanyak 3 siswa, nilai 9 sebanyak 12 siswa, nilai 8 sebanyak 15 siswa, dan nilai 7 sebanyak 10 siswa. Dengan demikian, tindakan 
perbaikan pembelajaran dianggap berhasil dengan baik.

$$
\text { Berdasarkan temuan data }
$$
penelitian pada siklus I dan II, baik berkenaan dengan hasil pembelajaran dan proses pelaksanaan pmbelajaran, maka dapat dilihat ada perbedaan antara data faktual dan ideal berdasar teori yang digunakan. Meskipun terdapat peningkatan, namun tetap bisa ditingkatkan lebih baik dan lebih optimal dalam penggunaan pendekatan metode keterampilan proses dan implikasinya terhadap hasil belajar yang dicapai siswa kelas $\mathrm{V}$ dapat mengembangkan, yakni dalam hal:

a) pengelompokkan untuk setiap kelompok kerja mempertimbangkan kemampuan peserta didik

b) dengan memperhatikan durasi pembelajaran yang terbatas, maka membagi kelompok dan menata ruang kelas terlebih dahulu dapat mengefektifkan kegiatan pembelajaran penggunaan pendekatan metode keterampilan proses dan implikasinya terhadap hasil belajar yang dicapai siswa kelas V

\section{KESIMPULAN DAN SARAN}

1. Peningkatan motivasi belajar yang dilakukan oleh guru pada siswa kelas $\mathrm{V}$ di SD Negeri Cigasong III. Kecamatan Cigasong Kabupaten Majalengka, menunjukan bahwasannya belum maksimal, oleh karena itu, maka hendaknya seorang guru tersebut harusnya telah mempersiapkan dengan sebaik-baiknya, akan segala sesuatu yang dibutuhkan sebelum melakukan proses pembelajaran yang akan dilaksanakannya di kelas.

2. Sedangkan dalam peningkatan motivasi belajar siswa kelas V di SD Negeri Cigasong III. Kecamatan Cigasong Kabupaten Majalengka, peningkatannya telah menunjukan hasil yang baik sekali, sebagaimana yang terlihat pada siklus I, memperoleh tanggapan ya 122 dan pada siklus II, memperoleh 160 Hal ini menujukan bahwasannya siswa mengalami peningkatan dari kedua respon yang telah dilakukan yaitu mencapai selisih 38 .

3. Adapun peningkatan motivasi belajar siswa kelas $\mathrm{V}$ dan implikasinya terhadap hasil belajar. di SD Negeri Cigasong III Kecamatan Cigasong Kabupaten Majalengka, berdasarkan penelitian yang dilakukan ini, telah menunjukan hasil belajar yang memuaskan, Dengan adanya gambaran tersebut, maka upaya peningkatan motivasi belajar siswa itu akan sangat berimplikasi terhadap hasil belajar siswanya.

Apabila kita perhatikan, bahwa berdasarkan dari hasil penelitian yang diperoleh itu, maka tentunya ada beberapa saran-saran yang hendak disampaikan, yang tujuannya agar ada masukan yang bisa bermanfaat, adapun saran-saran tersebut adalah sebagai berikut :

a. Guru tersebut hendaknya mampu membangun dalam proses belajar siswanya, yang seharusnyadapat memberikan motivasi terhadap belajar siswanya, agar apa yang diharapkan baik oleh guru itu sendiri maupun bagi siswanya akan dapat memperoleh suatu hasil belajar yang sesuai dengan apa yang diharapkan tentunya.

b. Diharapkan seorang guru membangkitkan motivasi siswa dan mampu mengelola proses pembelajaran dengan inovatif sehingga memberikan pengalaman baru pada diri siswa, tidak memberikan efek jenuh pada siswa sehingga siswa mampu belajar dengan maksimal yang berdampak pada mudahnya siswa menerima materi dengan baik.

c. Bagi Kepala Sekolah diharapkan mampu mendorong seluruh guru untuk melakukan penelitian tindakan kelas dalam rangka memperbaiki dan meningkatkan kualitas pembelajaran, sehingga pada akhirnya dapat 
meningkatkan hasil belajar siswa yang diharapkan khususnya pada pembelajaran IPA

d. Bagi Lembaga hendaknya memberikan sarana pendidikan khususnya alat dan media pembelajaran untuk menunjang ketercapaian tujuan pembelajaran sehingga kemampuan siswa berkembang secara maksimal dan bisa memberikan kontribusi yang baik pada sekolah.

\section{DAFTAR PUSTAKA}

Abdullah. 2013. Menjelajah pembelajaran inovatif. Jawa timur: Dampriyanto

Aqib 2013. Model-model dan strategi pembelajaran kontekstual (inovatif). Bandung.Y rama widya.

Arikunto, Suharsimi.(1997). Dasar-dasar evaluasi pendidikan : Aplikasi dan penerapannya. Jakarta: Bumi Aksara.

Bachri 2014. Strategi belajar mengajar (inovatif). Jakarta. PT. Rineka Cipta.

Daryanto. 2013.Media Pembelajaran. Yogyakarta. Gava Media.

Depdiknas. 2006. Bunga

Rampai

Keberhasilan Guru dalam Pembelajaran (SMA, SMK, dan $S L B)$. Jakarta: Depdiknas.

Dimyati dan Mudjiono. 2009. Belajar dan Pembelajaran. Jakarta: PT Rineka Cipta.

Djahiri, (1993).Landasan falsafah dan teori teknologi pendidikan, Media Kencana, IKIP Jakarta.

Faturrahman 2015. Strategi belajar mengajar. Jakarta PT Adi Mahasatya

Hamalik, Oemar. 2006. Proses Belajar Mengajar. Jakarta: PT Bumi Aksara
Hamdani. 2011. Strategi belajar mengajar. Bandung. CV Pustaka Setia

Martinis. 2010. Media pendidikan. Jakarta. Rajawali Press

Pollio. 2014. Strategi pembelajaran.jakarta. kencana. Prenada media group

Sardiman 2004. Interaksi dan motivasi belajar mengajar. Jakarta :Rajawali Press

Soemanto 2003. Psikologi pendidikan. Jakarta . PT. Rhineka Cipta.

Sudjana, Nana. 2010. Penilaian Hasil Proses Belajar Mengajar. (Cet. XV). Bandung: PT. Ramaja Rosdakarya.

Sukarno. Penelitian tindakan kelas dan penelitian tindakan sekolah beserta contoh-contohnya. Yogyakarta. Gava Media.

Sutisno. 2012. Telaah filsafat pendidikan. Yogyakarta. Deepublish

Syaiful 2011. Cooperative learning. Teori dan aplikasi paikem. Yogyakarta. Pustaka pelajar.

Syaiful Bahri Djamarah 2000, Bahan Pelajaran, Jakarta.

Trianto.2012 model pembelajaran terpadu dalam teori dan praktek. Jakarta. Prestasi pustaka raya.

Uno, Hamzah B., Abdul Karim Rauf, dan Najamuddin Petta Solong. 2008. Pengantar Teori Belajar dan Pembelajaran. (Cet. II). Gorontalo: Nurul Jannah.

Usman, Moh Uzer dan Lilis Setiawati. 2001. Upaya Optimalisasi Kegiatan Belajar Mengajar. Bandung: Remaja Rosdakarya. 
Wahidmurni, Alifin Mustikawan, dan Ali Ridho. 2010. Evaluasi

Pembelajaran: Kompetensi dan

Praktik. Yogyakarta: Nuha Letera.

Warner. 2013. Strategi belajar mengajar. Jakarta .direktorat jendral pendidikan tinggi.

Warsono. 2013 belajar aktif dan terpadu. Surabaya :Duta Graha

Yanto. 2013. Penelitian tindakan kelas. Jakarta . PT Bumi Aksara. 